\title{
Nigerianess versus Foreigness in the Calabar Festival and Carnival Calabar
}

\author{
Endong, Floribert Patrick C.
}

\author{
Department of Theatre and Media Studies, University of Calabar, Calabar-Nigeria
}

\begin{abstract}
The forces of culture commodification, cultural synchronisation and modernisation have been shaping, nay, disfiguring traditional cultural events staged in Africa. In a bid to modernise and render local cultures more appealing to a western/westernised public of tourists, many African states - particularly their tourism planners - have developed the tendency of copying and superimposing foreign/western concepts to local cultural displays. This paper illustrates this phenomenon using the Calabar Festival and Calabar Carnival (two popular cultural events staged in the Nigeria's South-eastern city of Calabar) as a case study. Using critical observations and secondary sources, this paper argues that for some years now, "controversial" and immodest forms of foreign cultures (particularly, nudity, pornography and lack of morality among others) have progressively disfigured the Calabar Festival and Carnival Calabar. The traditional conservative touch which used to characterise various aspects of these events has progressively been jettisoned in favour of westernisation (masked with modernisation or glamorisation of culture). While modernist Nigerians view such a growing influence of western/foreign cultures on the Calabar Festival and Carnival Calabar as an index of the inevitable dynamism of local cultures; conservative Nigerians uncompromisingly sound alarmist and rightly interpret such a phenomenon as a subtle disfiguration, erosion nay, disappearance of local cultures.
\end{abstract}

Keywords- Cultural Synchronisation, Culture Commoditisation, Glocalisation, Calabar Carnival, Calabar Festival.

\section{INTRODUCTION}

Art and cultural events are popularly viewed as vectors par excellence of the celebration, exhibition, promotion and commercialisation of culture. Events such as festivals, carnivals, art exhibitions and art workshops among others, are fertile forums through which specific cultural artefacts and industries are encouraged and exhibited for multidimensional appreciation. Besides having various commercial components, these events are, in theory, conceived to facilitate the nurturing and potential glorification of various core values (particularly the positive ones), shared by the culture(s) being exhibited through the events. In tandem with this, a tourist who attends a typical traditional African festival or a folkloric art event stage-managed on African soil, is theoretically made to watch, enjoy and appreciate diverse aspects of traditional African art forms notably, traditional African dances, folk art, masquerades, traditional masks, traditional music and textiles among others. Such a tourist may equally be treated to activities that will expose and advertise various core African cultural values (communalism, ancestral worship, respect for authority and the elders, hospitality, solidarity, sense of sacredness of life, sense of good human relation, sense of the sacred and the sense of language and proverbs among others) [Emeka, 2014; Endong, 2016; Ezenagu \& Olatunji, 2014].

In Nigeria particularly, popular cultural events such as the Sango festival and Eyo festival (in Yoruba land), the Sharo/Shadi festival (in Fulani land), and the new yam festival (in Igbo land and South-eastern Nigeria) ${ }^{1}$ are noted for their uniqueness and artistic/cultural potentials. These festivals and many others actually exhibit multiple aspects of traditional Nigerian cultures. No doubt, they have constituted major attractions to curious, and adventurous foreign tourists and art connoisseurs, visiting the country (Esekong and Ekpenyong, 2012; Eyo 2011; Ezenagu \& Olatunji, 2014; Olutu, Olapate \& Ogidi, 2013). Corroborating this observation, Abah et al (2014), posit that the many and varied festivals staged managed by Nigerian communities continue to be colourful avenues through which the diverse and rich cultural heritage of the Nigerian peoples are showcased and celebrated. These festivals unfailingly feature a mix of artistic presentations, singing and dancing among other creative activities. Each of these diverse Nigerian cultures has one or multiple of its aspects that have "refused to lose relevance, in spite of the influences of modernisation and Western religions". In the same line of argument, Nigeria Jovajo Travels (2016) opines that Nigerian indigenous cultures and traditions have miraculously survived the onslaughts of western religion and modernisation and that the various festivals are veritable peep-holes into the authentic cultural heritage and the glorious past of the Nigerian people. As succinctly put by 
the organisation, "there is no better way to explore the rich cultural diversity of the Nigerian people than taking part in the celebration of its cultural festivals. These festivals celebrate tradition, heritage and the rich history of the people through colourful attires, artistic expositions and intriguing traditional rites" (Nigeria Jovajo Travels 2016:4).

Though extremely patriotic in nature, the common position adopted by Abah et al (2014) and Nigeria Navajo Travels (2016) above, is highly arguable and seemingly insincere. To an extent, such a postulation could even be described as a hasty generalisation. This is so as it remains observable that the "quasi indomitable" forces of modernisation, cultural globalisation particularly cultural synchronisation, cultural glocalisation and culture commodification - have progressively affected many aspects of local Nigerian art and cultural events to the extent that these events do not longer serve as promoters of exclusively local, national (Nigerian) cultures. (Endong, 2015; Olutu, Olapete \& Ogidi, 2013). In effect, thanks to culture commodification and modernism, many of these events (traditional African festivals or carnivals particularly) are today often repackaged and managed according to western or westernised models. Many have seriously been diminished in terms of authenticity as they now most often exhibit either an "adulterated version" of local cultures, a "roughly modified and offensive" version of these local cultures (what Tahana and Oppermann [1998:23-30] will call a "pseudo-culture"), or a simply westernised version of local cultural idioms. This has been, not without virulent criticism from conservative observers and attendants of these events. In other words, in the name of modernism and commoditisation of culture, some of these so dubbed African traditional festivals rather celebrate foreign cultures, more than they celebrate local/national ones. Their name as traditional African festivals is unarguably improper and "misleading" since their contents are complexly redefined or reconfigured, mostly in favour of western cultural values.

The negative cultural diagnostic presented above can, to an extent, be made with reference to the two popular cultural events of Calabar Festival and Carnival Calabar ${ }^{2}$ which, at their inception, were principally conceived to dominantly celebrate the rich diversity of Nigerian cultures, irrespective of their foreign origins. The Calabar Festival in particular was originally designed to commemorate the birth of Jesus Christ in a purely traditional African style, through colourful display of masquerades and traditional dances, as well as heavy consumption of local food and drinks (Esekong and Ekpenyong, 2012; Eyo, 2011), while Carnival Calabar is cloned after the popular Trinidad and Tobago carnival. This paper seeks to illustrate how the combined forces of cultural synchronisation, glocalisation and cultural commodification have progressively affected the authenticity of these two cultural and art events, metamorphosing them from two vectors of the promotion of the diversity of Nigerian cultures to prolific sites of a multifaceted westernisation. The paper is divided into three principal sections. The first section provides a conceptual illumination on cultural synchronisation, culture commodification and glocalisation. The second section offers a brief presentation of Calabar Festival and Carnival Calabar while the last section attempts to examine the two neologisms of Nigerianess and foreignness in the two cultural events under study.

\section{Conceptual and Theoretical Issues}

This section provides conceptual definitions of three terms/theories namely cultural synchronisation, culture commodification and glocalisation. As a neologism, cultural commodification can be defined as a situation in which cultural artefacts, or cultural events such as history, traditions, folk dances, ceremonies and rituals are viewed as - or simply transformed into - commodities/brands and marketed to the tourism industry. This definition draws on the popular conception of commodification as the transformation into commodity of ideas, concepts and items which originally are not products. It is easily discernible from the above given definitional illumination that the phenomenon (of culture commodification) stems from the market economy paradigm which drives almost all modern societies. In effect, today's world really deserves to be described as a market society, where everything is considered in terms of its monetary value (everything is commoditised). The Hedgehog Review (2015) defines a market society as one in which market and its categories of thought have come to increasingly dominate virtually all areas of human lives. In such a society, the language of money speaks powerfully in almost all realms of life. In market societies, everything is commoditised: from sperm to eggs as well as from online dating services to human organs. In the same line of thought, universities view their services in terms of commodities while seeing their students as consumers. So too, the tourism industry in many countries (particularly in the Third Worlds) has tended to "convert" any art or cultural event to a product that can be marketed to tourists. The forces of globalisation and capitalism have, to a relatively great extent, been the engines pushing the commodification of culture in developing countries. In tandem with this, Mowforth and Munt (1998:64) concede that the proliferation and intervention of capitalism into Africa and the other Third Worlds, have actually motivated the tourism industry to turn their countries 
(Third World places), landscapes and people into commodities.

Culture commodification is not inherently or automatically "aggressive" to a country's efforts towards cultural preservation, as it can rather spurred the tourism industry (of a country) into investing huge resources for the revival of art forms, crafts and other cultural attributes of various communities within that country. Such a policy may equally motivate a country to select relevant aspects of national cultures to restore, reconstruct and preserve. A case in point is the popular tendency by countries to resort to the restoration, reconstruction and preservation of specific historical sites, in guise of cultural selection and control. As have been highlighted by critics, culture commodification may motivate a country to look backward and extract symbolic and relevant artefacts as well as proud moments for the sake of preservation. However, culture commodification policies/programs also constitute an immeasurable risk to the survival of local cultures, especially when considered from a practical point of view. In effect, the commodification of culture is susceptible to affect the experiential authenticity of art and cultural events (cultural tourism products). As applied to performing arts, experiential authenticity is associable with the idea of "living history". In concrete terms, experiential authenticity concerns itself with 'perfect simulation', replication of a past, an isomorphism or similarity of structural form '[...] between a living-history activity or event, and that piece of the past it is meant to re-create" (Handler and Saxton cited in Anonymous, 2014, para. 3). These simulations and recreations of the "living history" ineluctably engender a series of "magic moments", moments during which the sensation of experiencing the past becomes a present reality. This is to say that in actively demonstrating the past, the past becomes 'really real.

Culture commodification often affects the authenticity of cultural events in that, the reasons for which these events are performed are not the same as those which used to motivate their staging in normal circumstances. Given the fact that authenticity means more than seeming real to original performers, it may be impossible to claim to be authentic when the primordial motivation of staging an art or cultural event is financial. A traditional African performing art situation may be created basically for tourists and sometimes to the taste of these tourists, while overlooking the core inherent quality and meaning of the traditional performance. The fact that performers have strong economic motives to earn an income from their (re)production often - nay ineluctably - causes performance to loose in terms of authenticity. Performances are, in such context, subtly twisted to the taste of (mostly western or westernised) tourists; this, to the detriment of the original meaning and significance of the cultural event. Culture commodification thus presents the danger of reducing and sanitising religious rituals, traditional ethnic rites and festivals so that they conform to tourist expectations. Such a scenario may engender what the United Nations Environment Programme [UNEP], (2012) calls "reconstructed ethnicity". The UNEP further observes that, the selling of historical and symbolic sites as tourism product may engender the devalorisation and profanation of sacred sites while other sacred objects may not be respected.

In guise of culture commodification, a good number of African communities have systematically modified, repackaged and rebranded some of their festivals and cultural events, integrating a wide range of marginal activities/schemes susceptible to generate them enormous economic dividends. Using Cross River $\mathrm{State}^{3}$ as a case study, Omagu (2011) observes that beauty pageant, soccer competition, fashion parades, dance competition and best farmer competitions among others constitute some of the activities used by endogenous communities to modify or modernise their new yam festival and make them more appealing to tourists and more or less westernised Nigerian youths. These marginal activities have great economic significance to the host communities as they create both direct and indirect employment. The Cross River State (through its tourism industry) has equally integrated such lucrative activities into local festivals in a bid to transform these cultural events into more competitive brands, and create unparalled marketing opportunities for local and international brands (Cross River State Government, 2011; Omagu, 2011). Corroborating this position, Onah (Chairman of the State Carnival Committee), confides that the State will continue to view tourism cultural products as their "oil" that is, as a major and inestimable source of revenues. As he succinctly puts it, "tourism is indeed our own oil. We will use tourism to market the state to the world" (as cited in Akan, 2015, para 15).

The second key term employed in the present discourse is cultural synchronisation, a concept often regarded as a contemporary facet or manifestation of cultural imperialism, cultural homogenisation, cultural hegemony or cultural dependency (Arowolo, 2010; Endong, 2015; Hamelink, 1996; Mohammadi, 1996; Umeogu \& Ifeoma, 2012). Hamelink thus defines cultural synchronisation as a complex process by which the decisions bordering on modelling cultural development in a given country are made in accordance with the ideology, interests and needs of a powerful central nation, and "imposed with subtle but devastating effectiveness, without regard for the adaptive necessities of the dependent nation" (p.364). The nature of cultural influence occurring in a cultural 
synchronisation scenario is not formal, clear cut, very visible and straight. It is for this reason that Umeogu and Ifeoma (2012) give a simplified conceptualisation of the phenomenon. They concede that cultural synchronisation refers to a situation in which one community or society is consciously or unconsciously dependent on another as its main inspiration for cultural beliefs and practices. To buttress their conception, they used the metaphoric image of the dependence of a servant/slave on his master for all directives on any enterprise, as they note that the term (cultural synchronisation) "often conjures a recurrent image of a master and a dependant resulting in a situation where the dependant thrives on the hand-me-downs from the master" (Umeogu and Ifeoma 2012: 123).

Black African tourism planners as well as black African art and cultural event organisers/managers have, these last decades been some of the principal agents of cultural dependency or cultural synchronisation within the tourism industry. In a bid to attract and satisfy an ever-growing public of westernised and western tourists, they have developed the tendency of "spicing up" and "presumably" modernising art exhibitions, festivals, carnivals and many other of the cultural events they staged, with western ideas, concepts and activities. Such approaches have turned out to erode local cultures in a subtle and phenomenal way (Gambia Information Site, 2014; Richards, 2002; Wels, 2002). The UNEP (2012) succinctly deplores this scenario when it concedes that African destinations have been risking standardization in the process of satisfying tourists' desires for both familiar facilities and familiar cultural events. The organisation (the UNEP) further explains the dualism in African countries' style of managing tourism and cultural events which wants that, while landscape, accommodation, food, drinks, and cultural tourism products "must meet the tourists' desire for the new and unfamiliar, they must at the same time not be too new or strange because few tourists are actually looking for completely new things. Tourists often look for recognizable facilities in an unfamiliar environment, like well-known fast-food restaurants and hotel chains" (UNEP, 2012: 45). Arowolo (2010) principally attributes the prevalence of cultural synchronisation in most art and cultural events organised in Africa, to African policy designers and cultural event managers' inferiority complex and advanced degree of mental slavery. Such inferiority complex and mental slavery dispose them to glorify and conceive what so ever is purely western as a modern, irresistible and normative paradigm, irrespective of the dangers some of these imported ideas may pose to the survival of local cultures. "Westerness" is thus considered the "standard" and "a must", in any efforts towards planning tourism as well as in managing any art and cultural event envisaged to be international. Arowolo (2010:10) thus succinctly observes that:

Africa has been very weak and vulnerable since the last century. Africa now suffers from advanced level of mental enslavement [and] cultural imperialism. [There is pressing] need for decolonisation of Africa's mind. The trend of Western civilisation in Africa is pathetic, the strength of wave of Western civilisation is such that Africa is hardly capable of resisting it. The wave is so strong that it has become irresistible.

The third conceptual term considered in this section of our discourse is glocalisation, a portmanteau neologism composed of two words: "globalisation" and "localisation". As a phenomenon, glocalisation provides space for both the global and the local (Endong 2014). It represents a facet of hybridisation/creolisation as it enables the blending of both the foreign and the local. No doubt, it is generally conceptualised as a situation in which a product or an event intended for a global audience or public is systematically customised to suit local cultural sensibilities or taste. In the same line of though, Brooks and Normore (2010:52) define it as "the meaningful integration of global and local forces" for the creation of a dynamic and unique cultural product.

The glocalisation paradigm is said to govern cultural tourism or cultural event management in a country in a scenario where the global is not an aggressive or hegemonic force which subsumes the local. In such a context, the global is rather actively and assiduously courted by the local. Glocalisation in the tourism sector is thus seen in the creation of art and cultural events by statutory boards, in a bid to attract global tourists, rather than targeting only a local public. This however does not mean that "the local is wholly in thrall to the global as strategic decision-making also incorporates the needs of local communities and reflects their ethos" (Foley, Mcpherson \& Matheson, 2006:10). This discourse will principally hinged on Afro Tourism's (2015) conception of glocalisation in the domain of tourism as a kind of ingenuity manifested by the act by African tourism planers of blending local cultural traditions with western influences, "to put African [cultural products] on the global map".

\section{Calabar Festival and Carnival Calabar: A Brief Presentation}

Calabar festival is a 32 day Christmas festival organised annually within the South-eastern Nigerian city of Calabar. It begins on the $30^{\text {th }}$ November with a tree lighting ceremony and culminates with an interdenominational service on the $31^{\text {st }}$ of January. The festival which started ordinarily as a simple religious event meant to celebrate the birth of Jesus Christ with a 
traditional African touch (integrating a colourful display of masquerades and traditional dances among other cultural displays), has drastically/dramatically been reconfigured in the course of years, to integrate a mix of cultural, recreational, sportive, public health, intellectual and commercial activities. Most editions of the festivals have been structured with series of HIV/AID sensitisation campaigns, musical concerts, cultural events, football competition, beauty pageant, fashion show, culinary competitions, dance competitions, carnival essay competition, boat regatta and a carnival among other activities.

The HIV/AIDS sensitisation campaign takes the form of a city walk against HIV/AIDS staged at the preliminary stage of the festival. This activity is powered by HIV/AIDS advocacy groups and agencies and is aimed to commemorate World AIDS Day in the State (Cross River State of Nigeria). The walk which is attended by youths, NGOs and public and private sectors from all the Local Government Areas of the State, actually marks the debut of an annual summit dedicated to increasing awareness of the HIV/AIDS pandemics. The idea of organising this walk is partially to ensure fitness of the State's citizens in advance and during the main activities of the festival. According to Esekong and Ekpenyong (2012), the City Walk Against HIV/AIDS could equally be seen as a "test run for Carnival Calabar" given the fact that the $12 \mathrm{Km}$ walk goes through the same route.

Various musical concerts equally constitute a major component of the festival. These concerts include Calabar Music festival: roots, rock, reggae; Calabar gospel festival: praise night; Ladies night out; Calabar music festival: Calabar rocks; Jazz in Paradise, Canaan Rhythms; and Voices of Paradise among others. Other recreational and religious activities include the Nativity Play and carol Night, Funkadelik and Governor's Masked Fete among others. Sportive activities in the festival include the Calabar water carnival which consists of a boat regatta staged by participants [rowers] drawn from the riverine areas of the State as well as from the Southern States of Nigeria. The competition is organised in four categories namely, best decorated boat, most entertaining boat, best attired rowers and the winning boat. Other sportive activities of the festival include the Novelty football tournament (designed to raise money to aid the orphans and the aged), Mary Slessor Charity Golf Tournament, and Festival beach among others.

An integral part of the festival is the staging of traditional dances, masquerades, cultural dances, songs, dirges and poetry of various ethnic groups, often within the context of inter-state competition as well as competitions involving Local Government Areas ${ }^{5}$ within Cross River State. In some editions, these cultural activities are complemented by modelling parade of indigenous fashion, exhibiting the fashion and style of fabrics, beads, raffia and other accessories of the people of Cross River State and other Nigerian States. In addition to this modelling parade of local fashion, the festival includes another live fashion event headlined by both top Nigerian and international designers. With brand name "DCC Charity Fashion Show", this fashion show has, in some of its editions, offered a golden opportunity for celebrity design houses such as Jay-Z's Rocawear and Nelly's AppleBottoms to exhibit their collections. The fashion show has likewise permitted to Nigerian fashion designers such as Ituen Basi to exhibit their collections (Cross River State Government, 2011).

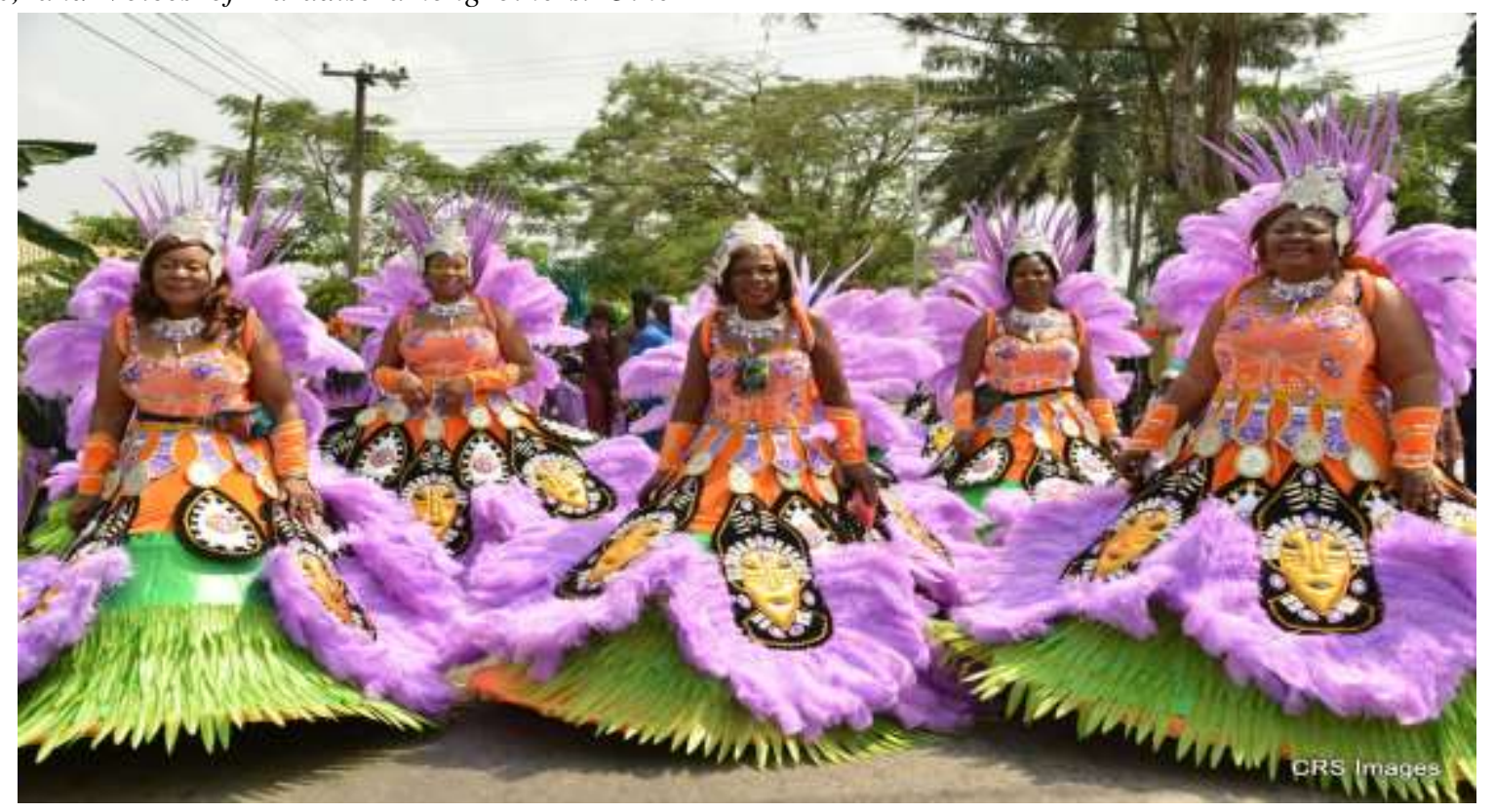

Plate.1: Revellers at the Calabar Carnival 
The most cardinal component of the festival is undoubtedly the Calabar carnival, brand-named, Carnival Calabar, and dubbed "Africa's Biggest Street Party". Cloned after the Trinidad and Tobago carnival, the event is a sensational display of a hybrid cultural spectacle including African heritage and foreign sensibilities. Being a veritable outpour of colour, sound and spectacle Carnival Calabar integrates music, dance, drama and a diversity of visual creativity. It is staged from the $26^{\text {th }}$ to the $27^{\text {th }}$ of December each year, a period considered the climax of the Calabar Festival. Considered the largest cultural festival in Africa and a veritable pot-pourri of cultures, the event involves over 50000 costumed revellers and 50000 spectators. In effect, Carnival Calabar ordinarily involves five bands namely the Bayside, Freedom, Master Blaster, Passion 4 and Seagull. The 2015 edition exceptionally added a sixth band christened Ayade's Band. Each of these bands are ordinarily headed by a leader who, in concert with prominent members of the State Carnival Commission (the government regulatory agency), conceives a philosophical and artistic framework for his/her group. The carnival bands have an indeterminate size, and are constituted by members of the general public. Sometimes they are integrated by Nigerian cinema gurus, music divas and other celebrities within the field of entertainment. The bands compete in interpreting the carnival theme defined well in advance by the State Carnival Commission. The five above mentioned band are circumstantially complemented by foreign bands often drawn from Caribbean countries. The inclusion of these foreign bands has often been to increase international participation in the Calabar Carnival.

The Calabar carnival is organised in three cardinal phases including the children carnival, the cultural carnival and the main carnival (often called adult carnival). The Children carnival is a well coordinated parade of children, divided into bands and clothed in colourful costumes. This parade is, so to speak, part of the preamble to the main carnival (the other part being the cultural carnival). The involvement of children through this carnival is symbolic in that it marks the passing of the carnival tradition from old generations to younger ones. The second preliminary to the main carnival (cultural carnival) is a parade of by various cultural groups representing a selected number of Nigerian States and riverine communities of Cross River State. The main carnival on the other hand is a 14 Kilometre procession by over 50000 costume revellers. These three phases of the carnival are separate competitions in which bands are judged by a college of juries drawn from the academia, and from a variety of professions including entertainment and the arts among others.

\section{Nigerianess in the Calabar Festival and Carnival} Calabar

Otherwise called "Nigerianity", the term Nigerianess is a neologism, often used in reference to anything pertaining to Nigeria. The term is visibly elusive and has thus been variously defined. Nigerianity is often defined in contrast or by analogy to "foreignness" which is the fact of being foreign or sharing foreign heritage. In line with this, Nigerianess is viewed as the fact of being Nigerian or of sharing Nigerian heritage. However, some authors have viewed Nigerianess in the act by Nigerians (producers/event managers) of packaging cultural products about Nigeria and for Nigerians (Kolbowe and Madu, 2012). This definition may not fully apply to the context of our discourse since the Calabar festival and Carnival Calabar are definitely not packaged exclusively for a Nigerian public of consumers. In this essay, Nigerianess will simplistically be conceptualised as indices that can clearly be associated with core traditional Nigerian values, as highlighted by Emeka (2012). These core cultural values include: i) sense of community life; (ii) sense of good human relations; (iii) sense of the sacredness of life; (iv) sense of hospitality; (v) sense of the sacred and of religion; (vi) sense of time; (vii) sense of respect for authority and the elders; (viii) sense of language and proverbs.

Nigerianess, in the Calabar Festival and Carnival Calabar is manifested in a number of ways/areas, one of which is the fact that the two cultural events are the fruits of the successful indigenisation of two foreign concepts. As earlier underlined, the Calabar Festival stemmed out of Cross River State Tourism Bureau's idea of localising the celebration of the birth of Jesus Christ; that is, celebrating Christmas with a traditional African touch, through the integration of traditional dances, masquerades and heavy consumption of local dishes and drink to the feast. Through this scenario, the event organisers have artfully coated a tenet of an imported religion (Christianity) with numerous local cultural idioms (local festival such as the Nyoro festival of the Ekpe masquerade). Likewise, the Calabar carnival is cloned after the Trinidad and Tobago carnival but is largely executed according to local cultural sensibilities. No doubt, scholars such as Esekong and Ekpenyong have described the event as a foreign carnival tradition "on which indigenous art forms and festivals have been sprinkled" so to speak, for local acceptability (Esekong and Ekpenyong 2012:291). Early editions of the carnival in particular, thrived to diminish if not exclude factors that could, according to local sensibilities, be read as immorality and pornography. An egregious example is the fact that early editions of the Calabar carnival emphasised on the rendering of revellers' costumes with a touch of traditional Nigerian morality and conservatism. 
With this, costumes were usually less revealing than those generally exhibited in foreign/western carnivals notably, in Rio de Janeiro carnival and Trinidad and Tobago among others. At the conceptual level, it can be enthused that, the Calabar Festival and Calabar Carnival are the

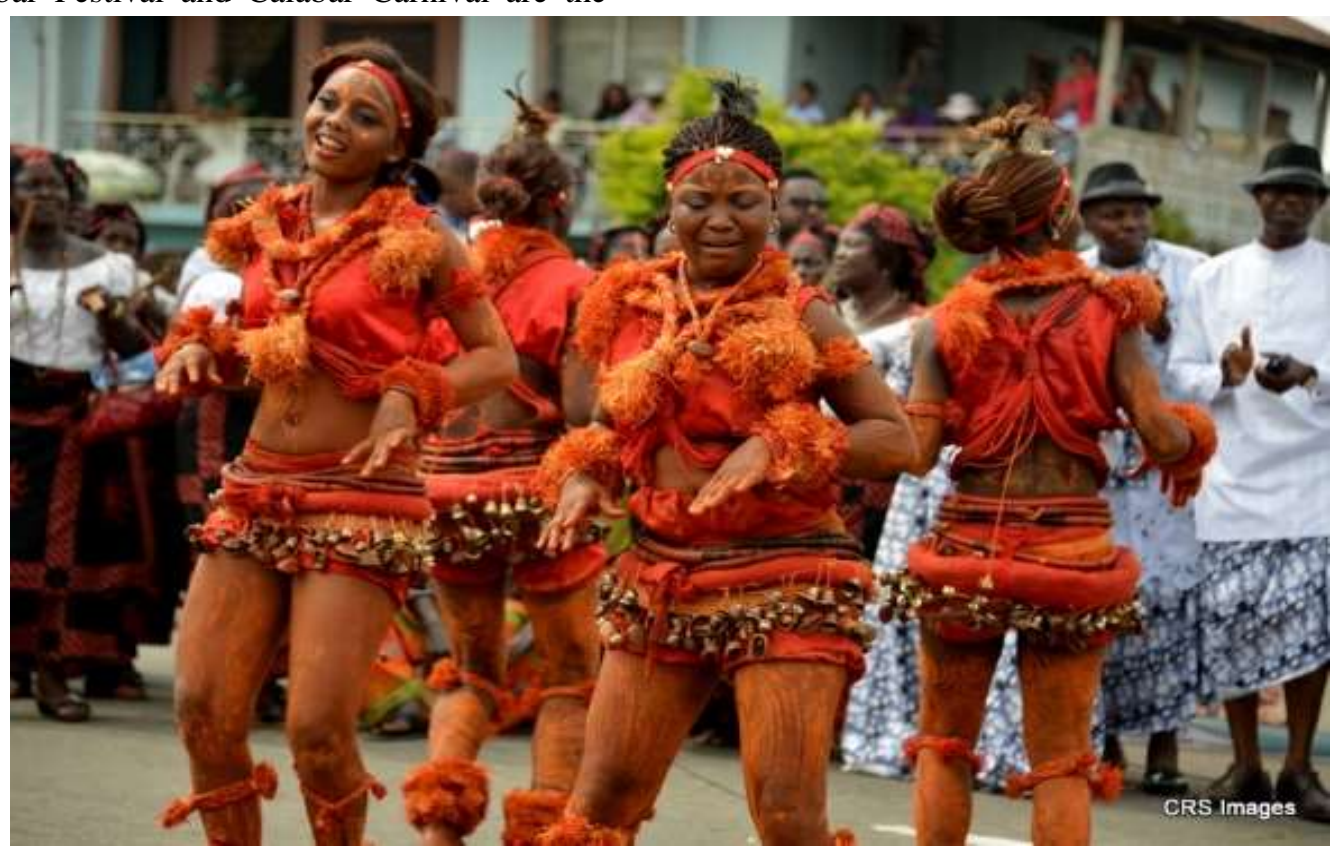

Plate.2: Traditional Dancers at the Cultural Carnival

The Calabar festival integrates a variety of cultural events which really exhibit African and Nigerian heritage. Among these events, one may mention traditional dances, masquerades, dirges and traditional poetry. Though diminished to an extent, in terms of authenticity, the cultural and sportive event of Calabar Water Carnival is strongly reminiscent of the boat regatta often organised by the riverine ethnic groups in special occasions. In the olden days boat regattas were staged to spice up festivities over the coronation of a new Efik king (called the Obong) brilliant results of the Cross River government's initiative of glamorising, modernising, popularising and promoting the ancient practice of making fun out the marking of the end of year in Calabar.

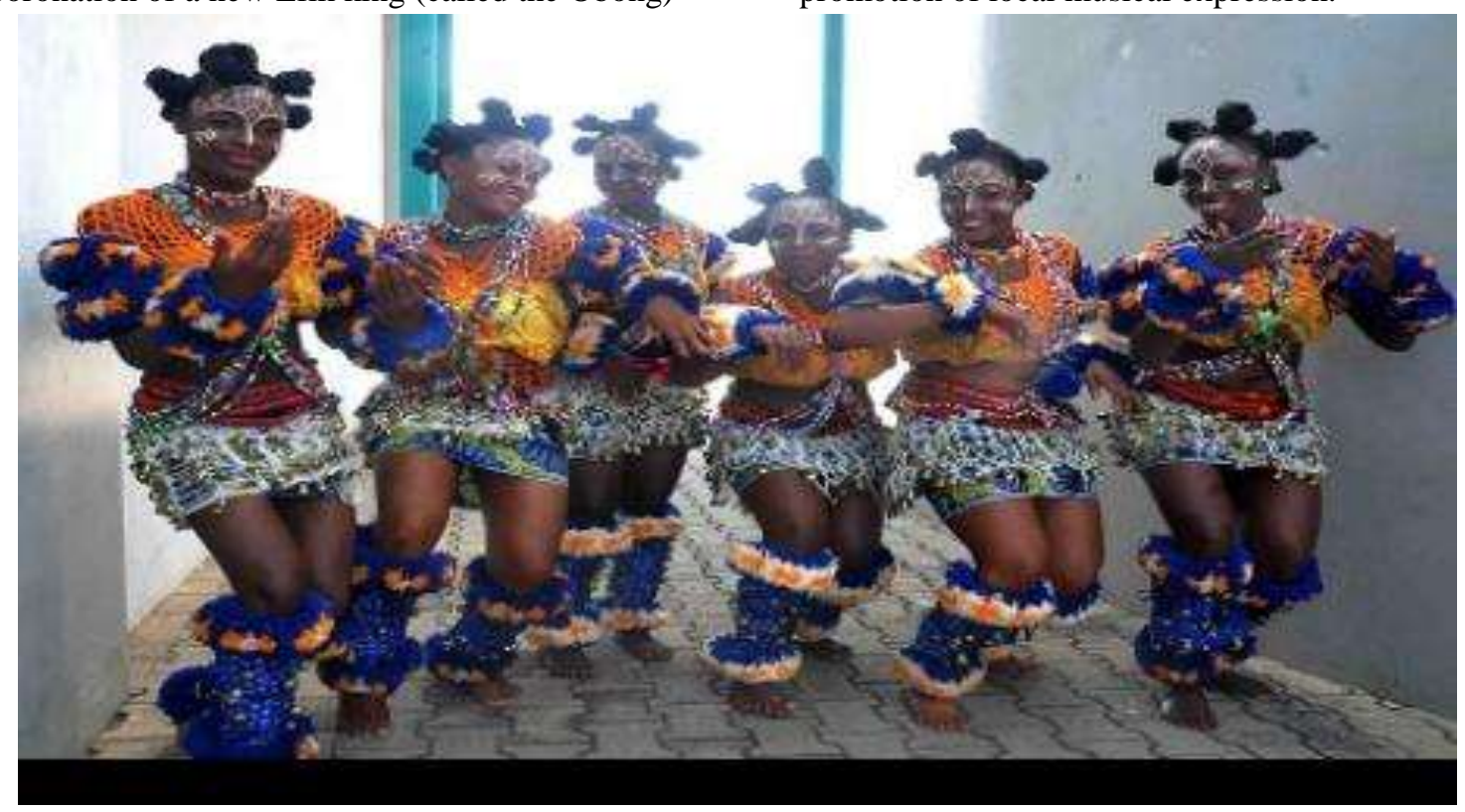

Plate.3: Traditional Dancers at Cultural Carnival

or over war victories. Other events such as musical concerts (particularly the Calabar Music Festival [Naija most wanted category]), promote Nigerian music in particular as it features popular hip-hop and R\&B stars from the country exclusively. Though the hip-hop and R\&B genres could arguably be given American/western origins, the strands of hip-hop and $R \& B$ produced by these local musicians within the context of these concerts are highly glocalised, and so, represent sites of the promotion of local musical expression.

$-$ 
Cultural events such as the cultural parade, (one of the preliminaries to the main Calabar carnival) and even the main carnival are equally sites of the display and promotion of local cultures. Though punctuated with a number of foreign cultural artefacts (for instance the American hip-hop music), the two parades dominantly display various aspects of African heritage. The cultural parade in particular always showcases a colourful spectacles by revellers adorned with ethnic costumes and traditional dresses. This parade in particular can be described as a strong symbol of Nigerian cultural diversity and socio-political unity.

\section{Foreignness in Calabar Carnival and Calabar Festival}

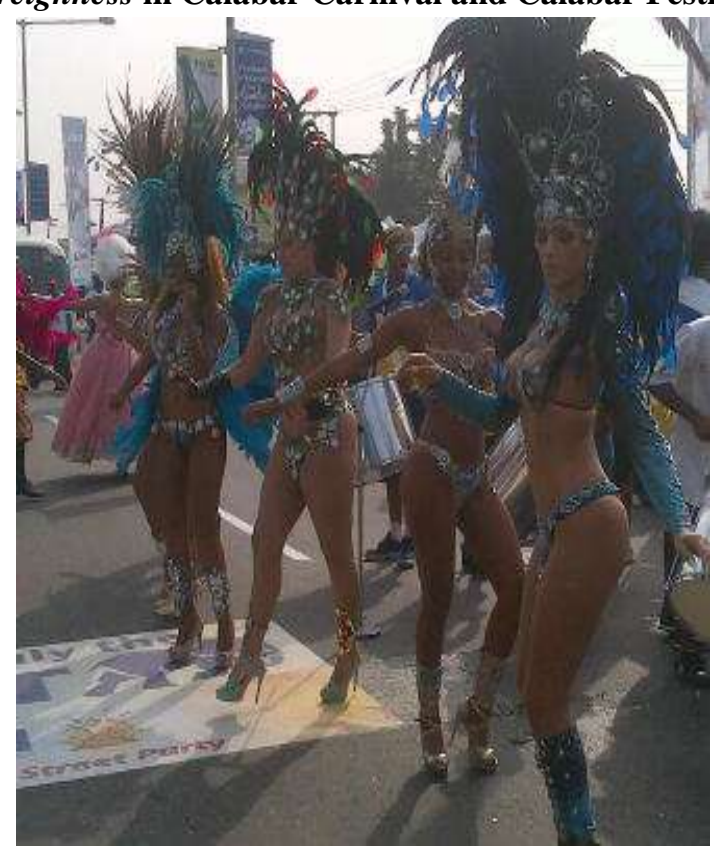

Plate.4: A View of the Brazilian Band (Vai-Vai Samba)

In a visible bid to attract more audiences and ensure a greater patronage of local historical sites and leisure establishments by both endogenous and exogenous publics, the Calabar Festival and Carnival Calabar organisers have resorted to multiple strategies, some of which have often been very controversial. Three of these strategies have been to rebrand, reconfigure and repackage the two cultural events, integrating more foreign concepts. The artful incorporation of these foreign concepts have visibly been in a way as to make these events more appealing to a modernised, westernised, if not western audience. This position can egregiously be evidenced by the fact that the State Carnival Commission, has in recent editions of Carnival Calabar, adopted the paradigm of integrating Caribbean and western bands to its pool of active participants to the events. This choice has enabled bands from Brazil, Trinidad and Tobago, Spain and France to circumstantially be part and indirect controllers of the festivities. A (negative) by-product of this idea has often been the display - by these foreign bands - of a spectacle which seriously hurts and seems to overlook local conservative sensibilities.

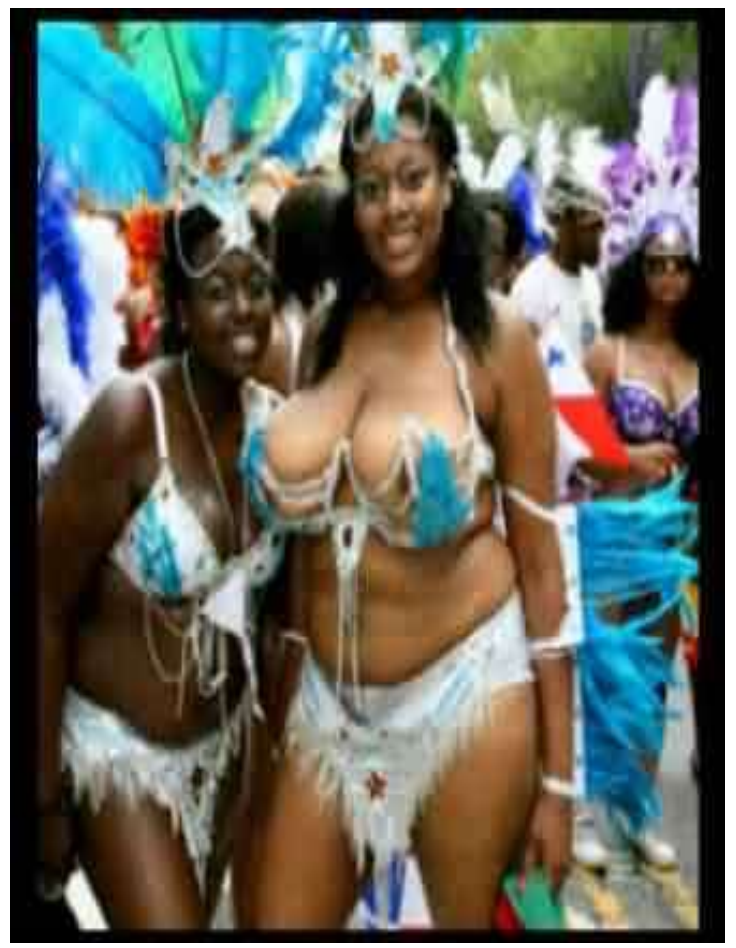

Plate.5: Imitators of the Vai-Vai Samba

Brazilian and Trinidadian bands have often exhibited a carnival tradition which is close to nudity (nay pornography) and which African and endogenous publics have impulsively considered obscene and un-African/unNigerian (Eyo, 2012; Omagu 2014). The 2012 to 2015 editions of the Calabar Carnival have, for instance, featured Caribbean bands (such as the Vai-Vai Samba) in their various parades. These exclusively female teams always adorned themselves with virtually naked and provocative costumes (see plates 4, 5 and 6) and dance seductively round the major routes of Calabar, enticing other female participants to copy their adornment and dance-steps. It is based on such socio-cultural indexes that many indigenous people arguably view tourism and the commodification of local cultures as a serious menace to African/Nigerian cultural values and a factor creating disconnect of local people from cultural traditions. Because of its increasing Caribbean accent and its nudity/pornographic contents, observers have tended this last years to (re)brand the Calabar Carnival a Caribbean festival, somehow dissociating the event from genuine promotion of local cultures. Omagu (2014) makes allusion to such a scenario in his critique of the 2012 and 2013 editions of the Calabar carnival. He pointedly observes that the Caribbean brands have, through their "cult to nudity" culturally contaminated local publics, particularly female participants in the carnival. As he explains, "in a "monkey see, monkey do" style, other 
Nigerian women participants quickly [have been adorning] themselves with such see-through panties so as to catch attention. Dancing step-by-step and dexterously to the carnival music, thousands of onlookers, especially young men, said it loudly how provoked they were by the seductresses from foreign lands" (Omagu 2014:13).

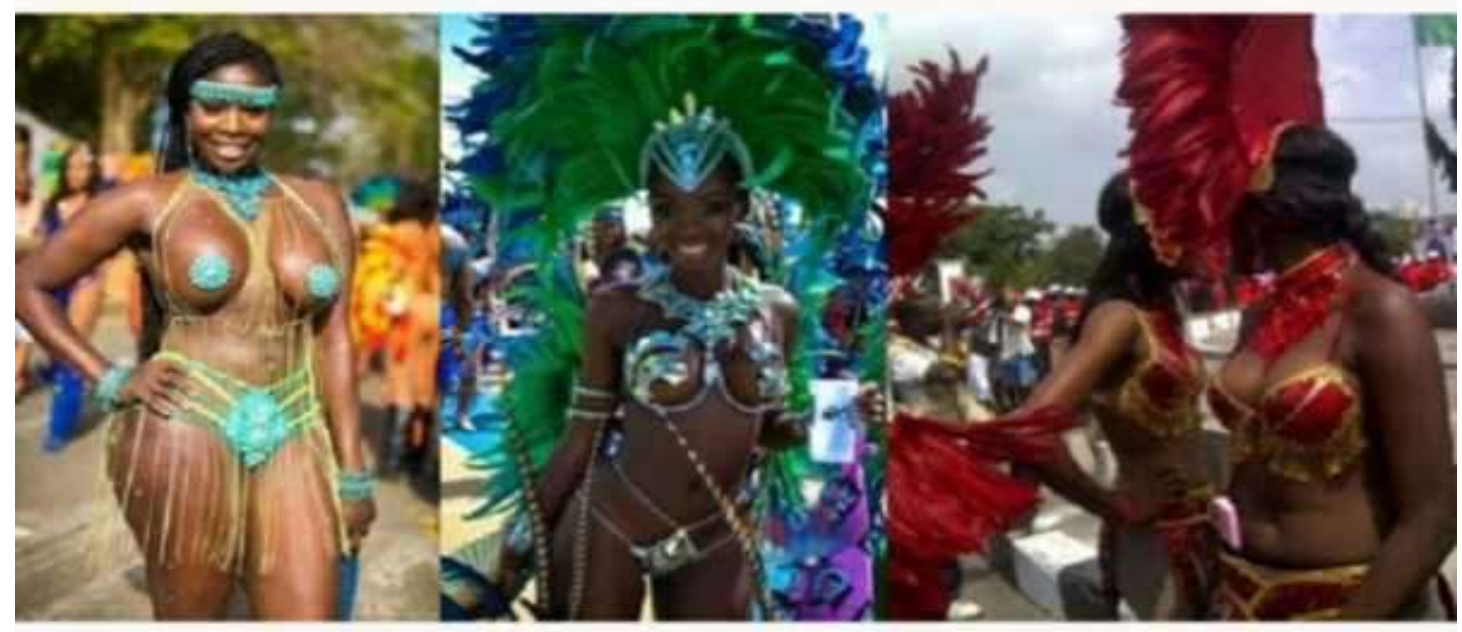

Plate.6: Samba Dancers at the Calabar Carnival

It is important to emphasise here that nudity and pornography - whatsoever the form they take - have most often been considered by (conservative) Africans as a western permissive culture (Endong and Veraba 2015; Ojo, 2008). Based on this premise, the inclusion of such artefacts as nudity and pornography to any traditional African cultural events may likely and largely be interpreted as a form of western cultural pollution (westoxification) and a gross attempt at cultural imperialism/cultural synchronisation. In line with this, most conservative - particularly religiously inclined observers and opinion leaders from the riverine communities of Cross River State have profiled and branded the Calabar Festival and Calabar Carnival as strong promoters of a foreign culture, principally on the ground of their nudity contents. Such observers have strongly censured and "disowned" the bulk of the cultural traditions exhibited through the Calabar Festival and Calabar Carnival. As case in point is Bishop Archibong Archibong - Chairman of the Christian Association of Nigerian (CAN) Cross River Chapter - who, in an acerb mode, slams the Calabar Carnival on such cultural grounds. He hastily and summarily associates the event with offensive nudity, lack of modesty, lack of morality and pure westerness/westernisation. He enthuses that:

We need to be very careful [with] the way we are now going in this carnival thing. We are completely forgetting about morals. The way people dance is now sexual, it shows that there is no shame among our women; there is no modesty.

The people [foreigners/westerners] came in and borrowing us the culture that is not our culture and women staying almost naked only with pants and brassier. I don't think it is good for this State or any part of the nation; it is not our culture and I believe strongly that we should not encourage it. (as cited in Bassey, 2014, para 12-3)

The staunchest and most pessimistic "detractors" of the Calabar festival and Calabar carnival view government sponsorship and management of the events as a pure wastage of scares governmental funds. Such observers view government's powering of the events as a culturally non-sensitive ploy, which rather facilitates the importation of a mix of foreign cultures that promote promiscuity, prostitution, thereby increasing the rate of HIV/AIDS in the State (Eyo, 2011). Apart from the nudity/pornographic contents, other features - such as American hip-hop music, rock and gospel - have, in the course of years, given more foreign accents to some of the activities staged in the Calabar Festival and Calabar Carnival. Some of the various concerts organised within the context of the festival are sites of the display of these aspects of the American/western culture. An egregious example is the Calabar Music Festival: Calabar Rocks which, as a highlight of the festival, features performances by major international superstars. Past editions of this event have featured performances of superstars notably, Keri Hilson, Wyclef and Akon among others. Also, the hip-hop genre is constantly used during the carnival parades to substitute the Caribbean Samba.

The "injection" of various foreign/western cultural artefacts into the festival has been part of annual innovations in the two events. The principal organisers of these two cultural events and the State government view 
such innovations as efforts to transform - and arguably modernise/refine - local cultures, thus as a positive development. This is not surprising as right from the beginning, the organisers of the events - the same as the State administration - had predicted the dynamism of these cultural events. This dynamism - which happens to be a progressive westernisation of the various cultural displays of the festival - is rather interpreted by government officials as a lucrative modernisation of local cultures. As pungently remarked by Ben Ayade (Governor of the State) at the end of the 2015 edition of the Calabar Festival, "since culture is dynamic, it must grow and we must modernise our culture to reflect the growth of Africa" (as cited in Premium Times, 2015).

\section{CONCLUSION}

The Calabar Festival and Carnival Calabar are two egregious examples of a pot-pourri of cultures. The two events are rapidly changing and their future cultural configuration is clearly unpredictable. This has partially been predicated on the ingenious efforts by the Cross River State government towards the systematic commoditisation of local cultures and the development of the tourism sector as an alternative - if not principal source of dividends. The government has pursued such an aggressive socio-cultural policy since 2003 in the guise of glamorising and modernising local cultures. Since the administration of Mr. Donald Duke - the government which actually gave a dramatic bent to the two events successive governments (governors) of the State have made it their prerogative to add colours to the festival and to commoditise, glamorise and popularise these cultural products the more. These commoditisation, glamorisation and modernisation of local cultures have however yielded a form of cultural synchronisation, westernisation and cultural imperialism. More foreign concepts have been integrated into the festival. It is our observation in this discourse that, for some years now, "aggressive" and immodest forms of foreign cultures (particularly, nudity, pornography and lack of morality among others) have been progressively disfiguring the Calabar Festival and Carnival Calabar. The traditional conservative touch which used to characterise various aspects of these events is progressively rejected in favour of westernisation (masked with modernisation or glamorisation of culture). The Nigerian modernists will quickly view such a development (the growing influence of western/foreign cultures on the Calabar Festival and Carnival Calabar) as an index of the inevitable dynamism of local cultures. However, the conservatives will uncompromisingly sound alarmist and rightly interpret such a phenomenon as a subtle and progressive disfiguration, erosion nay, disappearance of indigenous cultural traditions.

\section{Notes}

${ }^{1}$ The Yoruba, Igbo and Fulani constitute major ethnolinguistic groups within the Nigerian Federation. They respectively occupy the South-western, South-eastern and Northern portions/geo-political zones of the Nigerian territory.

${ }^{2}$ Calabar is the capital city of Cross River State of Nigeria. The autochthonous tribe in Calabar is Efik.

${ }^{3}$ Cross River State is situated at the South-eastern part of Nigeria. It is bounded at the North-east by the Southwestern region of the republic of Cameroon.

${ }^{4}$ Crude oil is Nigeria's major source of income. There have been various forms of advocacy by critics, politicians and technocrats in favour of the diversification of the Nigerian economy, particularly the exploration of alternative sources of incomes for the Federation. It is in line with this that successive Cross River State governments (governors) have been working actively towards developing the tourism industry as an alternative source of income for the State.

5 The Local Government Area is one of the smallest units of administration in the Nigerian territorial administration system.

\section{REFERENCES}

[1] Abah, A. et al (2014). 'Nigeria's 10 famous festival'. Leadership Newspaper, March 14 edition, 38-39.

[2] Afro Tourism (2015). Banjul: Glocalising Fashion. $<$ http://www.103.15.67.74/pro1/afrotourismnew/banjul-glocalising-fashion/ $>\quad$ Accessed May 31, 2016.

[3] Akan, J. (2015). 'Calabar Carnival 2015: Music, Dancing and Costumes at Africa Biggest Street Party'. Pulse. <http://www.calabarcarnival-2015.music-dancing-and- costumes-atafrica-biggest-street-party/pulse.htm.> Accessed May 30, 2016.

[4] Annonymous (2014). 'Culture as a Commodity: Consumerism and Authenticity'. <http://wwwculture-as-a-commodity.htm/> Accessed May 30, 2016.

[5] Bassey, J. (2014). 'Moral Lesson on Calabar Carnival'. The Ink Newspaper. $<$ http://www.moral-lesson-on-calabar-carnivalby-joy-bassey-welcome-to-the- official-blogof-the-ink-newspaper-uyo-akwa-ibom-state.htm.> Accesses May 30, 2016.

[6] Brooks, J. S. and Normore, A.H. (2010). 'Educational leadership and globalisation: literacy for a global perspective'. Educational Policy, 24(1), 52-83. 
[7] Cross River State Government (2011). Calabar Festival. make your brand the star. Calabar:

Brand House Communications Limited.

[8] Emeka, A. (2014). African Cultural Values. <http://www.emeka.at\%2Fafrican_cultural_vaules.p df\&usg=AFQjCNE30utItcG7XsbdR3DN913O3p6wg\&sig2=i8AEKQ6Xd-BEsFZbtHmSSQ> Accessed June 1, 2016.

[9] Endong, F. P. C. \& Vareba, A.L. (2015). 'Condemning pornography in the open, enjoying it in secrete: a content analysis of online commenters' perception of soft porn in Nollywood films'. Social and Basic Sciences Research Review, 3(10), 354-363.

[10] Endong, F.P.C. (2015). 'Indigenisation of media in Nigeria and cultural globalisation: mutual bedfellows or implacable arch foes?' Journal of Globalization Studies, 6(2), 106-118.

[11]Esekong, H. A. and Ekpenyong, I. (2012). 'Promoting culture and tourism in Nigeria through Calabar festival and carnival Calabar'. Mediterranean Journal of Social Sciences, 3(3), 287-294.

[12]Eyo, C. (2011). 'Calabar Carnival Serves Taste of Efik Culture'. Daily Trust. <http://www.calabarcarnival-serves-taste-of-efik-culture/daily-trust.htm> Accessed May 30, 2016.

[13] Ezenagu, N. and Olatunji, T. (2014). 'Harnessing Awka traditional festival for tourism promotion'. Global Journal of Arts Humanities and Social Sciences, 2(5), 43-56.

[14]Foley, M.,, Mcpherson, G. and Matheason, C. (2006). 'Glocalisation and Singaporean festivals'. International Journal of Event Management Research, 2(1), 1-16.

[15]Gambia Information Site (2014). Ethical and Responsible Tourism in Gambia.

<http://www.accessgambia.com/information/ecotourism-responsible.html> Accessed June 1, 2016,

[16]Getz, D. and Page, S.J. (2016). 'Progress and prospects for events tourism research'. Tourism Management, 52, 393-432.

[17]Hamelink, C. (1996). 'Cultural imperialism and national identity. cultural autonomy threatened'. In Hanson J and Maxcy D. (eds) Sources: Notable Selection in Mass Communication, New York: Deskin Publishing Group/Brown and Benchmark Publishers.

[18]Kebba, D. (2014). 'The Kanilai International Cultural Festival: Cultural Diplomacy'. Daily Observer.

<http://archive.observer.gm/africa/gambia/article/the -kanilai-international- cultural-festival-culturaldiplomacy-in-perspective> Accessed May 31, 2016.

[19] Kolbowe, O., \& Madu, O. (2012). 'Programming content of Nigerian broadcast media: towards and indigenisation paradigm'. Estudos em Comunicacao, 1(8), 75-91

[20] Mohammadi, A. (1996). 'Cultural imperialism and national identity'. In Hanson J and Maxcy D. (eds) Sources: Notable Selection in Mass Communication, New York: Deskin Publishing Group/Brown and Benchmark Publishers.

[21] Mowforth, M. and Munt, I. (1998). Tourism and sustainability: new tourism in the third world. London: Routledge.

[22] Nigeria Jovago Travel (2016). '5 Vibrant Cultural Festivals in Nigeria'. Jovago Travels <http://www.5vibrant-cultural-festivals-innigeria/jovago-travel.com $>$. Accessed on the 27/05/2016.

[23]Ojo, A.O. (2005). Religion and sexuality. individuality, choice and sexual rights in Nigerian Christianity. Lagos: Africa Regional Sexuality Resource Centre.

[24] Olutu, O. A., Olapate, M. O. and Ogidi, A. E. (2013). 'Commodification of local culture and tradition for tourism development and sustainability in Nigeria: empirical evidence of Tiv and Idoma cultures in Benue State'. BJMASS: British Journal of Management and Social Sciences, 11(1), 105-128.

[25] Omagu, D. (2011). 'Cultural tourism in Cross River State: commodifaction or pluralism'. Ndunode:

Calabar Journal of Humanities, 11(1), 1-17.

[26]Pantelic, Z. and Curcic, B. (2015). Cultural commodification and its consequences on the neoliberal "nicche". Globalisation-Core Periphery Hierachies. <http://wwwculturalcommodification-and-its-consequences-in-theneoliberal-niche-globalization-core- peripheryhierachies-future-non-stop.htm> accessed May 30, 2016.

[27]Premium, Times (2015). 'Calabar Festival: Bauchi State Emerges Best Cultural Troupe, Wins N5 m Star Price'. Premium Times. <http:www.calabarfestival-bauchi-state-emerges- best-cultural-troupewins-n5m-star-price/premium-times/nigeria.htm> Accessed May 302016.

[28]Richards, G. (2002). 'Satisfying the cultural tourist: challenges for the new millennium'. In Akama S.J. and Sterry, P. (eds), Cultural Tourism in Africa: Strategies for the New Millennium, Mombasa: ATLAS Cultural Tourism Research. 
[29] Tahana, N. and Oppermann, M. (1998). 'Maori cultural performances and tourism'. Tourism Recreation Research, 23(1), 23-30.

[30] The Hedgehog Review (2014). 'Editorial comment'. The Hedgehog Review, 23(1), i-ii.

[31] Umeogu, B. and Ifeoma, O. (2012). 'Cultural dependency : a philosophical insight'. Open Journal of Philosophy, 2(2), 123-127.

[32] United, Nations Environment Programme (2012). Negative socio-cultural impacts from tourism. change or loss of indigenous identity and values. New York: UNEP.

[33] Wels, H. (2002). A critical reflection on cultural tourism in Africa: the power of European imagery'. In Akama S.J. and Sterry, P. (eds), Cultural Tourism in Africa: Strategies for the New Millennium, Mombassa: ATLAS Cultural Tourism Research. 